University of Nebraska - Lincoln

DigitalCommons@University of Nebraska - Lincoln

Faculty Papers and Publications in Animal

Science

Animal Science Department

10-12-2004

\title{
Comparison of models including cytoplasmic effects for traits of Rambouillet sheep
}

G. D. Snowder

USDA, ARS, U.S. Meat Animal Research Center

K. J. Hanford

USDA, ARS, U.S. Meat Animal Research Center, kathy.hanford@unl.edu

L. Dale Van Vleck

University of Nebraska-Lincoln, dvan-vleck1@unl.edu

Follow this and additional works at: https://digitalcommons.unl.edu/animalscifacpub

Part of the Animal Sciences Commons

Snowder, G. D.; Hanford, K. J.; and Van Vleck, L. Dale, "Comparison of models including cytoplasmic effects for traits of Rambouillet sheep" (2004). Faculty Papers and Publications in Animal Science. 159. https://digitalcommons.unl.edu/animalscifacpub/159

This Article is brought to you for free and open access by the Animal Science Department at DigitalCommons@University of Nebraska - Lincoln. It has been accepted for inclusion in Faculty Papers and Publications in Animal Science by an authorized administrator of DigitalCommons@University of Nebraska - Lincoln. 


\title{
Comparison of models including cytoplasmic effects for traits of Rambouillet sheep ${ }^{\text {ts }}$
}

\author{
G.D. Snowder ${ }^{\mathrm{a}, *}$, K.J. Hanford ${ }^{\mathrm{b}}$, L.D. Van Vleck ${ }^{\mathrm{b}}$ \\ ${ }^{a}$ USDA, ARS, U.S. Meat Animal Research Center, P.O. Box 155, Clay Center, NE 68933, USA \\ ${ }^{\mathrm{b}}$ USDA, ARS, U.S. Meat Animal Research Center, Lincoln, NE 68583-0908, USA
}

Received 28 October 2003; received in revised form 22 March 2004; accepted 31 March 2004

\begin{abstract}
The objective was to determine appropriate analytical models considering cytoplasmic inheritance for birth weight (BWT, $n=35,604$ ), weaning weight (WWT, $n=34,114$ ), fleece weight (FWT, $n=38,113$ ) and number born $(\mathrm{NB}, n=39,029)$ for Rambouillet sheep. For BWT, models that included dam by year, dam by number born, and sire by dam effects, in addition to direct and maternal effects, were significantly better than the basic maternal effects model. For WWT, variances due to direct, maternal, and maternal permanent environmental effects ( 0.05 of variance) were not zero. For FWT, heritability was 0.55 for all models, but models with dam by year (0.02), sire by dam $(0.05)$, and sire by cytoplasmic line $(0.02)$ were jointly significantly better than models with permanent environmental effects. For NB, only direct heritability (0.08) and relative permanent environmental variance $(0.04)$ were not zero. No trait showed evidence of variation due to cytoplasmic effects. Adding seldom considered effects to the model did not change estimates of variance due to direct and maternal genetic effects. Variance due to dominance effects may be important for BWT and FWT. The basic direct-maternal effects model seems sufficient for genetic evaluations for WWT and FWT but models for BWT and NB may need to include other effects.

Published by Elsevier B.V.
\end{abstract}

Keywords: Birth weight; Weaning weight; Fleece weight; Litter size

\section{Introduction}

Mammalian mitochondrial DNA codes for only 37 genes (13 protein coding genes, 22 transfer RNA genes, and 2 ribosomal genes; Wolstenholme, 1992). When compared to the estimated 24,500 to 45,000

\footnotetext{
ts Published as paper no. 14529, Journal Ser., Nebraska Agric. Res. Div., University of Nebraska, Lincoln 68583-0908.

* Corresponding author. Tel.: +1-402-762-4167; fax: +1-402762-4173.

E-mail address: snowder@email.marc.usda.gov (G.D. Snowder).
}

protein coding genes in the mammalian genome (Pennisi, 2003), the mitochondrial DNA contributes less than $0.01 \%$ of the mammalian genome. The influence of mitochondrial DNA on phenotypic variation within some populations may be very small because recombination of parental genes cannot occur. A small number of sperm-derived mitochondria may be transferred to the oocyte during fertilization but these are usually degraded in embryogenesis (Sutovsky et al., 1996). Mitochondrial genes are subject to mutations (Hiendleder, 1998) and mitochondrial polymorphisms have been associated with 
small differences in production traits of dairy cattle (Boettcher et al., 1996a). Genetic evaluations that ignore significant cytoplasmic effects will bias estimates of heritability and animal breeding values (Boettcher et al., 1996b).

More recent studies of beef cattle (Tess and Robison, 1990) and dairy cattle (Boettcher and Gibson, 1997; Albuquerque et al., 1998) performance have found cytoplasmic effects on important production traits are very small in contrast to preliminary studies (Bell et al., 1985; Tess et al., 1987), which substantiated Kennedy (1986) who showed that failure to account for genetic drift with the numerator relationship matrix would result in overestimation of the importance of cytoplasmic effects. A study of five mitochondrial haplotypes in Japanese Black cattle found no significant differences for carcass traits except for marbling score (Mannen et al., 1998). A review of the effect of cytoplasmic inheritance on economically important traits in cattle concluded that cytoplasmic effects are very small and findings were often biased by the statistical analyses (Gibson et al., 1997).

Studies of cytoplasmic effects on traits of sheep have recently also shown cytoplasmic effects to be of little importance for growth of Suffolk lambs (Maniatis and Pollott, 2002) and for four representative traits (birth weight (BWT), weaning weight (WWT), fleece weight (FWT), and litter size at birth) for Targhee (Van Vleck et al., 2003) and for Columbia (Hanford et al., 2003) sheep. The latter two breeds are dual-purpose composite breeds of Rambouillet descent developed at the U.S. Sheep Experiment Station. Because the Rambouillet breed has a more historical pedigree than the recently developed composite breeds of Columbia and Targhee, the effect of cytoplasmic inheritance may differ in the Rambouillet. The purpose of this paper was to compare estimates of variance components due to cytoplasmic origin and due to the interaction of sire genotype with cytoplasmic origin for the Rambouillet breed with those previously reported for Columbia and Targhee breeds. Another purpose was to estimate components of variance due to interactions of dam with year, number born, and sire genotype, which were found to be important for birth weight in the studies of Columbia and Targhee sheep.

\section{Materials and methods}

Records available for analysis were collected from 1950 through 1998 at the United States Sheep Experiment Station (USSES), Dubois, Idaho. Hanford (2001) edited the records as part of a study to analyze genetic change over the 49 years. The number of records analyzed ranged from 34,119 to 39,029 depending on the trait of interest. General management of the flock under a western range grazing production system was described by Ercanbrack and Knight (1991).

Four traits were analyzed: birth weight, 120-day weaning weight, annual fleece weight, and number of lambs born. Birth weight and weaning weight were lamb traits, and fleece weight and number born were ewe traits. Table 1 shows number of records, means and number of levels for each trait and associated random factors. Fixed factors shown in Table 2 are the same as were used with the Columbia (Hanford et al., 2003) and Targhee (Van Vleck et al., 2003) analyses.

Female line of descent was traced to founding dams to establish cytoplasmic lines. If pedigrees

Table 1

Summary $^{\mathrm{a}}$ of number of records and of levels by factor for four traits

\begin{tabular}{|c|c|c|c|c|}
\hline & $\begin{array}{l}\text { Birth } \\
\text { weight }\end{array}$ & $\begin{array}{l}\text { Wean } \\
\text { weight }\end{array}$ & $\begin{array}{l}\text { Fleece } \\
\text { weight }\end{array}$ & $\begin{array}{l}\text { Number } \\
\text { born }\end{array}$ \\
\hline Number records ${ }^{b}$ & 35,604 & 34,114 & 38,113 & 39,029 \\
\hline Mean (wt., kg) & 4.68 & 32.3 & 4.65 & 1.34 \\
\hline S.D. (wt., kg) & 0.77 & 5.4 & 0.92 & 0.70 \\
\hline $\begin{array}{l}\text { Animals with } \\
\text { records }\end{array}$ & 35,604 & 34,114 & 10,420 & 10,634 \\
\hline Sires & 1830 & 1829 & 1626 & 1632 \\
\hline Dams & 9484 & 9384 & 5687 & 5787 \\
\hline Cytoplasmic line & 1577 & 1566 & 769 & 840 \\
\hline $\begin{array}{l}\text { Average } \\
\text { animals/line }\end{array}$ & 22.6 & 21.8 & 13.6 & 12.7 \\
\hline Dam $\times$ year & 26,656 & 26,259 & 9594 & 9785 \\
\hline Sire $\times$ dam & 25,534 & 25,161 & 9408 & 9599 \\
\hline $\begin{array}{l}\text { Sire } \times \\
\quad \text { cytoplasmic } \\
\text { line }\end{array}$ & 20,293 & 20,059 & 8278 & 8454 \\
\hline $\begin{array}{l}\text { Dam } \times \text { number } \\
\text { born }\end{array}$ & 14,329 & - & - & - \\
\hline
\end{tabular}

${ }^{a}$ Number of animals in pedigree file $=38,161$, number of genetic groups $=84$, up to 18 generations to founder dam.

${ }^{\mathrm{b}}$ Means and standard deviations not adjusted for model effects. 
Table 2

Number of levels for fixed factors in models for analysis of four traits (birth weight, BWT; wean weight, WWT; fleece weight, FLW; number born, NB)

\begin{tabular}{|c|c|c|c|c|}
\hline Factor & BWT & WWT & FLW & NB \\
\hline Year & 49 & 49 & 46 & 47 \\
\hline Age of dam (ewe) & 12 & 12 & (13) & (13) \\
\hline Gender & 2 & 3 & - & - \\
\hline Type of birth (TB) ${ }^{a}$ & 4 & - & - & - \\
\hline $\mathrm{TB}$ and rearing ${ }^{\mathrm{b}}$ & - & 8 & - & - \\
\hline Number weaned & - & - & 5 & - \\
\hline $\begin{array}{r}\text { Calendar day } \\
\text { (covariate) }\end{array}$ & - & - & $\swarrow$ & - \\
\hline
\end{tabular}

${ }^{a}$ Four types of birth: single, twin, triplet, quadruplet.

${ }^{\mathrm{b}}$ Eight TB and rearing levels: single-single, single-twin, twinsingle, twin-twin, triplet/quadruplet-single, triplet/quadruplettwin, triplet/quadruplet-triplet, quadruplet-any type of rearing.

before 1950 had been available, fewer lines may have been found (Roughsedge et al., 2001). Columbia sheep all trace to Rambouillet ewes, as do most of the Targhee population (Terrill, 1947). Effects of variance due to effects of sire by cytoplasmic line interaction were used as a measure of the interaction of nuclear and mitochondrial genomes. Recent studies have identified enzymes composed of both nuclear and mitochondrial origin, such as cytochrome $c$ oxidase, a mammalian enzyme containing 13 polypeptides of which three are encoded by the mitochondrial genome and 10 encoded in the nucleus (Wolz et al., 1997).

Birth weight was analyzed first with the usual direct-maternal effects model plus cytoplasmic line effects and genotype by cytoplasmic line effects. In addition, a dam by year interaction effect was included to resemble a sire by year interaction effect. (Sires did not repeat over years.) With the previous Targhee and Columbia analyses, the variance component for dam by year effects was relatively large, accounting for $10 \%$ to $12 \%$ of phenotypic variance. Because multiple births were the only way a dam could have more than one progeny per year, dam by year effects are equivalent to litter effects (Al-Shorepy and Notter, 1998). To determine if that variation could be accounted for by litter size or a full sib effect, dam by number born and dam by sire effects were added to the model. What is apparent (Table 1) is that the various dam by other factor interaction effects are highly confounded. After cytoplasmic effects were found not to be important, separation of variation due to maternal permanent environmental effects, dam by year, dam by number born, and dam by sire interaction effects was attempted. With other traits, variance due to dam by year effects was small so that fewer models were examined. For the ewe traits of fleece weight and number born with repeated measures, both animal and maternal permanent environmental effects were sometimes both included in the model. Random factors in the models are shown in Table 3.

Analyses were conducted with 84 founder genetic groups and without founder genetic groups (Westell et al., 1988). Founder groups were assigned by Hanford (2001) based on year of birth of an animal for the animal's sire and dam when they did not have a record. Estimates of relative (fraction of phenotypic) variance components were similar with or without groups in the model. Thus, only the full and usual models were used for analyses with groups in the model to reduce computing time and costs.

Variance components were estimated with REML by a derivative-free algorithm (Smith and Graser, 1986) using the MTDFREML programs (Boldman et al., 1995). Approximate standard errors of estimates of the parameters (fractions of phenotypic variance) used the average information matrix (Johnson and Thompson, 1995) and the delta method (e.g., Dodenhoff et al., 1998). Likelihood ratio tests (LRT) were used to test whether random effects contributed significantly to the likelihood given the data.

Table 3

Possible random factors in models for analyses of four traits (birth weight, BWT; wean weight, WWT; fleece weight, FLW; number born, NB)

\begin{tabular}{|c|c|c|c|c|}
\hline Factor & BWT & WWT & FLW & NB \\
\hline Animal genetic, $a^{2}$ & $\swarrow$ & $\swarrow$ & $\swarrow$ & $\swarrow$ \\
\hline Maternal genetic, $m^{2}$ & $\swarrow$ & $\swarrow$ & $\swarrow$ & $\swarrow$ \\
\hline Correlation, $r_{\mathrm{am}}$ & $\swarrow$ & $\swarrow$ & - & - \\
\hline $\begin{array}{l}\text { Maternal permanent } \\
\text { environmental, } p_{\mathrm{M}}^{2}\end{array}$ & $\swarrow$ & $\swarrow$ & $\swarrow$ & 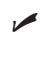 \\
\hline $\begin{array}{l}\text { Animal permanent } \\
\text { environmental, } p_{A}^{2}\end{array}$ & - & - & $\mathscr{V}$ & $\swarrow$ \\
\hline Cytoplasmic line, $c^{2}$ & $\swarrow$ & $\mathscr{\swarrow}$ & $\swarrow$ & $\swarrow$ \\
\hline Dam $\times$ year, $d y^{2}$ & $\swarrow$ & $\swarrow$ & $\swarrow$ & $\swarrow$ \\
\hline Dam $\times$ number born, $d n^{2}$ & $\swarrow$ & - & - & - \\
\hline Sire $\times$ dam, $d s^{2}$ & $\prec$ & $\swarrow$ & $\swarrow$ & $\swarrow$ \\
\hline Sire $\times$ cytoplasmic line, $s c^{2}$ & $\swarrow$ & $\swarrow$ & $\swarrow$ & $\swarrow$ \\
\hline
\end{tabular}




\section{Results and discussion}

In agreement with the previous studies of Columbia and Targhee sheep (Hanford et al., 2003; Van Vleck et al., 2002), which were contemporaries of the Rambouillet at USSES, no evidence was found for effects of cytoplasmic line on any of the four traits (birth weight in Table 4, weaning weight in Table 5, fleece weight in Table 6, and number born in Table 7). These results agreed with the Columbia and Targhee analyses and were not surprising given the preponderance of Rambouillet cytoplasm in the development of the Columbia and Targhee composite breeds. The result also agrees with estimates of Maniatis and Pollott (2002) for Suffolk growth traits.

The only trait that expressed possible effects of interaction of sire genotype and cytoplasmic line was fleece weight (Table 6), which also was in agreement with the Columbia and Targhee analyses. The fraction of variance due to that interaction was only 0.02 . What is surprising is that all three breeds thus far studied have shown significant sire by cytoplasmic line effects for fleece weight only and with no detectable variance due to cytoplasmic effects. The lack of variance due to cytoplasmic effects may indicate that the interaction variance is due to confounding with other effects not in the model.

For all traits and in agreement with the previous analyses with contemporaneous Columbia and Targhee data, whether or not founder genetic groups were in the model resulted in none to little change in estimates of genetic parameters. Thus, with groups in the model, only analyses with the usual model and the full model were done and are reported in the first two rows of Tables 4-7. Various reduced models without group effects were done and are also reported. For all four traits, the estimates of variance components as fractions of phenotypic variance, with minor

Table 4

Estimates of genetic parameters ${ }^{\mathrm{a}}$ for birth weight with 16 models with standard errors (S.E.) for complete model $^{\mathrm{b}}$

\begin{tabular}{|c|c|c|c|c|c|c|c|c|c|c|c|}
\hline \multirow[t]{2}{*}{ Model } & \multicolumn{11}{|c|}{ Parameters } \\
\hline & $a^{2}$ & $r_{\mathrm{am}}$ & $m^{2}$ & $p^{2}$ & $c^{2}$ & $d y^{2}$ & $d n^{2}$ & $s d^{2}$ & $s c^{2}$ & $e^{2}$ & $2 \log L$ \\
\hline \multicolumn{12}{|c|}{ Models with genetic groups } \\
\hline 1 & 0.27 & 0.03 & 0.19 & 0.07 & - & - & - & - & - & 0.46 & $0.00^{\mathrm{c}}$ \\
\hline 2 & 0.27 & 0.05 & 0.19 & 0.05 & 0.00 & 0.08 & - & 0.03 & 0.00 & 0.37 & $221.09^{\mathrm{c}}$ \\
\hline \multicolumn{12}{|c|}{ Models without genetic groups } \\
\hline 3 & 0.26 & 0.02 & 0.19 & 0.07 & - & - & - & - & - & 0.47 & $0.00^{\mathrm{d}}$ \\
\hline 4 & 0.27 & 0.03 & 0.19 & 0.07 & 0.00 & - & - & - & - & 0.47 & $0.00^{\mathrm{d}}$ \\
\hline 5 & 0.26 & 0.05 & 0.19 & 0.06 & - & 0.11 & - & - & - & 0.37 & $216.69^{d}$ \\
\hline 6 & 0.25 & 0.03 & 0.26 & - & - & 0.12 & - & - & - & 0.37 & $166.63^{d}$ \\
\hline 7 & 0.26 & 0.03 & 0.20 & 0.03 & - & - & 0.06 & - & - & 0.44 & $102.99^{\mathrm{d}}$ \\
\hline 8 & 0.26 & 0.05 & 0.19 & 0.04 & - & 0.10 & 0.04 & - & - & 0.37 & $247.21^{\mathrm{d}}$ \\
\hline 9 & 0.26 & 0.05 & 0.19 & 0.05 & - & - & - & 0.10 & - & 0.38 & $200.48^{\mathrm{d}}$ \\
\hline 10 & 0.26 & 0.05 & 0.19 & 0.05 & 0.00 & - & - & 0.10 & - & 0.38 & $200.47^{\mathrm{d}}$ \\
\hline 11 & 0.26 & 0.05 & 0.19 & 0.06 & 0.00 & - & - & - & 0.05 & 0.42 & $94.79^{\mathrm{d}}$ \\
\hline 12 & 0.26 & 0.05 & 0.19 & 0.05 & 0.00 & - & - & 0.10 & 0.00 & 0.38 & $200.78^{\mathrm{d}}$ \\
\hline 13 & 0.26 & 0.05 & 0.19 & 0.05 & - & 0.08 & - & 0.04 & - & 0.37 & $220.34^{\mathrm{d}}$ \\
\hline 14 & 0.26 & 0.05 & 0.19 & 0.03 & - & 0.06 & 0.04 & 0.04 & - & 0.37 & $250.28^{\mathrm{d}}$ \\
\hline 15 & 0.26 & 0.05 & 0.19 & 0.05 & 0.00 & 0.08 & - & 0.03 & 0.00 & 0.37 & $220.50^{\mathrm{d}}$ \\
\hline 16 & 0.26 & 0.05 & 0.19 & 0.03 & 0.00 & 0.06 & 0.04 & 0.03 & 0.00 & 0.37 & $250.46^{\mathrm{d}}$ \\
\hline S.E. & $0.015^{\mathrm{b}}$ & $0.046^{\mathrm{b}}$ & $0.014^{\mathrm{b}}$ & $0.009^{\mathrm{b}}$ & $0.003^{\mathrm{b}}$ & $0.018^{\mathrm{b}}$ & $0.009^{\mathrm{b}}$ & $0.019^{\mathrm{b}}$ & $0.007^{\mathrm{b}}$ & $0.011^{\mathrm{b}}$ & \\
\hline
\end{tabular}

${ }^{\text {a }}$ Proportional variance: $a^{2}$, direct genetic; $r_{\mathrm{am}}$, direct-maternal genetic correlation; $\mathrm{m}^{2}$, maternal genetic; $p^{2}$, maternal permanent environmental; $c^{2}$, cytoplasmic line; $d y^{2}$, dam by year; $d n^{2}$, dam by number born; $s d^{2}$, sire by dam; $s c^{2}$, sire by cytoplasmic line; $e^{2}$, temporary environmental; phenotypic variance: 0.3968 to 0.4062 .

${ }^{\mathrm{b}}$ Model not including genetic groups.

${ }^{\mathrm{c}}$ Difference in $2 \log$ likelihood from usual model $\left(1: a^{2}, r_{\mathrm{am}}, \mathrm{m}^{2}, p^{2}\right)$ with genetic groups in model.

${ }^{\mathrm{d}}$ Difference in $2 \log$ likelihood from usual model $\left(3: a^{2}, r_{\mathrm{am}}, \mathrm{m}^{2}, p^{2}\right)$ with genetic groups not in model. 
Table 5

Estimates of genetic parameters ${ }^{\mathrm{a}}$ for weaning weight with 11 models with standard errors (S.E.) for complete model $^{\mathrm{b}}$

\begin{tabular}{|c|c|c|c|c|c|c|c|c|c|c|}
\hline \multirow[t]{2}{*}{ Model } & \multicolumn{10}{|c|}{ Parameters } \\
\hline & $a^{2}$ & $r_{\mathrm{am}}$ & $m^{2}$ & $p^{2}$ & $c^{2}$ & $d y^{2}$ & $s d^{2}$ & $s c^{2}$ & $e^{2}$ & $2 \log L$ \\
\hline \multicolumn{11}{|c|}{ Models with genetic groups } \\
\hline 1 & 0.20 & 0.33 & 0.10 & 0.04 & - & - & - & - & 0.60 & $0.00^{\mathrm{c}}$ \\
\hline 2 & 0.20 & 0.33 & 0.10 & 0.04 & 0.00 & 0.00 & 0.00 & 0.00 & 0.60 & $2.75^{\mathrm{c}}$ \\
\hline \multicolumn{11}{|c|}{ Models without genetic groups } \\
\hline 3 & 0.18 & 0.30 & 0.10 & 0.05 & - & - & - & - & 0.63 & $0.00^{\mathrm{d}}$ \\
\hline 4 & 0.18 & 0.30 & 0.10 & 0.05 & 0.00 & - & - & - & 0.63 & $0.01^{\mathrm{d}}$ \\
\hline 5 & 0.18 & 0.30 & 0.10 & 0.05 & - & 0.00 & - & - & 0.63 & $0.01^{\mathrm{d}}$ \\
\hline 6 & 0.18 & 0.30 & 0.10 & 0.05 & - & - & 0.00 & - & 0.63 & $0.00^{\mathrm{d}}$ \\
\hline 7 & 0.18 & 0.31 & 0.10 & 0.05 & 0.00 & - & - & 0.00 & 0.62 & $0.35^{\mathrm{d}}$ \\
\hline 8 & 0.18 & 0.31 & 0.10 & 0.05 & 0.00 & - & 0.00 & - & 0.63 & $0.01^{\mathrm{d}}$ \\
\hline 9 & 0.18 & 0.31 & 0.10 & 0.05 & 0.00 & - & - & 0.00 & 0.62 & $0.34^{\mathrm{d}}$ \\
\hline 10 & 0.18 & 0.31 & 0.10 & 0.05 & 0.00 & - & 0.00 & 0.00 & 0.62 & $0.30^{\mathrm{d}}$ \\
\hline 11 & 0.18 & 0.31 & 0.10 & 0.05 & 0.00 & 0.00 & 0.00 & 0.00 & 0.62 & $0.34^{\mathrm{d}}$ \\
\hline S.E. & $0.012^{\mathrm{b}}$ & $0.070^{\mathrm{b}}$ & $0.011^{\mathrm{b}}$ & $0.008^{\mathrm{b}}$ & $0.002^{\mathrm{b}}$ & $0.022^{\mathrm{b}}$ & $0.021^{\mathrm{b}}$ & $0.007^{\mathrm{b}}$ & $0.013^{\mathrm{b}}$ & \\
\hline
\end{tabular}

${ }^{\mathrm{a}}$ Proportional variance: $a^{2}$, direct genetic; $r_{\mathrm{am}}$, direct-maternal genetic correlation; $\mathrm{m}^{2}$, maternal genetic; $p^{2}$, maternal permanent environmental; $c^{2}$, cytoplasmic line; $d y^{2}$, dam by year; $s d^{2}$, sire by dam; $s c^{2}$, sire by cytoplasmic line; $e^{2}$, temporary environmental; phenotypic variance: 19.41 to $19.78 \mathrm{~kg}^{2}$.

${ }^{\mathrm{b}}$ Model not including genetic groups.

${ }^{\mathrm{c}}$ Difference in $2 \log$ likelihood from usual model $\left(1: a^{2}, r_{\mathrm{am}}, m^{2}, p^{2}\right)$ with genetic groups in model.

${ }^{\mathrm{d}}$ Difference in $2 \log$ likelihood from usual model (3: $\left.a^{2}, r_{\mathrm{am}}, \mathrm{m}^{2}, p^{2}\right)$ with genetic groups not in model.

exceptions, were for practical purposes, the same as with models for Columbia and Targhee records that have been reported and discussed (Hanford et al.,
2003; Van Vleck et al., 2003). Therefore, only exceptions and general patterns will be discussed by trait for the Rambouillet analyses.

Table 6

Estimates of genetic parameters ${ }^{\mathrm{a}}$ for fleece weight with 10 models with standard errors (S.E.) for complete model $^{\mathrm{b}}$

\begin{tabular}{|c|c|c|c|c|c|c|c|c|c|c|}
\hline \multirow[t]{2}{*}{ Model } & \multicolumn{10}{|c|}{ Parameters } \\
\hline & $a^{2}$ & $m^{2}$ & $p_{\mathrm{m}}^{2}$ & $\mathrm{p}_{\mathrm{a}}^{2}$ & $c^{2}$ & $d y^{2}$ & $s d^{2}$ & $s c^{2}$ & $e^{2}$ & $2 \log L$ \\
\hline \multicolumn{11}{|c|}{ Models with genetic groups } \\
\hline 1 & 0.54 & 0.02 & 0.01 & 0.11 & - & - & - & - & 0.34 & $0.00^{\mathrm{c}}$ \\
\hline 2 & 0.54 & 0.01 & 0.00 & 0.04 & 0.00 & 0.02 & 0.04 & 0.02 & 0.33 & $23.03^{\mathrm{c}}$ \\
\hline \multicolumn{11}{|c|}{ Models without genetic groups } \\
\hline 3 & 0.55 & 0.02 & 0.01 & 0.10 & - & - & - & - & 0.33 & $0.00^{\mathrm{d}}$ \\
\hline 4 & 0.56 & - & 0.02 & 0.10 & - & - & - & - & 0.33 & $3.57^{\mathrm{d}}$ \\
\hline 5 & 0.56 & - & - & 0.11 & - & - & - & - & 0.33 & $11.11^{\mathrm{d}}$ \\
\hline 6 & 0.55 & 0.02 & - & 0.03 & - & 0.08 & - & - & 0.33 & $17.73^{\mathrm{d}}$ \\
\hline 7 & 0.56 & 0.02 & - & - & - & 0.10 & - & - & 0.32 & $14.66^{\mathrm{d}}$ \\
\hline 8 & 0.54 & 0.02 & - & 0.07 & - & - & - & 0.04 & 0.33 & $13.13^{\mathrm{d}}$ \\
\hline 9 & 0.55 & 0.02 & - & 0.03 & - & 0.06 & - & 0.02 & 0.33 & $21.84^{\mathrm{d}}$ \\
\hline 10 & 0.55 & 0.01 & 0.00 & 0.03 & 0.00 & 0.02 & 0.05 & 0.02 & 0.33 & $23.99^{d}$ \\
\hline S.E. & $0.016^{\mathrm{b}}$ & $0.009^{\mathrm{b}}$ & $0.008^{b}$ & $0.019^{\mathrm{b}}$ & $0.003^{\mathrm{b}}$ & $0.035^{\mathrm{b}}$ & $0.033^{\mathrm{b}}$ & $0.012^{\mathrm{b}}$ & $0.005^{\mathrm{b}}$ & \\
\hline
\end{tabular}

${ }^{\text {a }}$ Proportional variance: $a^{2}$, direct genetic; $m^{2}$, maternal genetic; $p^{2}$, maternal permanent environmental; $c^{2}$, cytoplasmic line; $d y^{2}$, dam by year; $s d^{2}$, sire by dam; $s c^{2}$, sire by cytoplasmic line; $e^{2}$, temporary environmental; phenotypic variance: 0.5916 to $0.6032 \mathrm{~kg}^{2}$.

${ }^{\mathrm{b}}$ Model not including genetic groups.

${ }^{\mathrm{c}}$ Difference in $2 \log$ likelihood from usual model $\left(1: a^{2}, m^{2}, p_{\mathrm{m}}^{2}, p_{\mathrm{a}}^{2}\right)$ with genetic groups in model.

${ }^{\mathrm{d}}$ Difference in $2 \log$ likelihood from usual model (3: $\left.a^{2}, m^{2}, p_{\mathrm{m}}^{2}, p_{\mathrm{a}}^{2}\right)$ with genetic groups not in model. 
Table 7

Estimates of genetic parameters ${ }^{\mathrm{a}}$ for number born with eight models with standard errors (S.E.) for complete model ${ }^{\mathrm{b}}$

\begin{tabular}{|c|c|c|c|c|c|c|c|c|c|c|}
\hline \multirow[t]{2}{*}{ Model } & \multicolumn{10}{|c|}{ Parameters } \\
\hline & $a^{2}$ & $m^{2}$ & $p_{\mathrm{m}}^{2}$ & $p_{\mathrm{a}}^{2}$ & $c^{2}$ & $d y^{2}$ & $s d^{2}$ & $s c^{2}$ & $e^{2}$ & $2 \log L$ \\
\hline \multicolumn{11}{|c|}{ Models with genetic groups } \\
\hline 1 & 0.09 & 0.00 & 0.00 & 0.04 & - & - & - & - & 0.87 & $0.00^{\mathrm{c}}$ \\
\hline 2 & 0.09 & 0.00 & 0.00 & 0.04 & 0.00 & 0.00 & 0.00 & 0.00 & 0.87 & $2.51^{\mathrm{c}}$ \\
\hline \multicolumn{11}{|c|}{ Models without genetic groups } \\
\hline 3 & 0.08 & 0.00 & 0.00 & 0.04 & - & - & - & - & 0.87 & $0.00^{\mathrm{c}}$ \\
\hline 4 & 0.09 & - & - & 0.04 & - & 0.00 & - & 0.00 & 0.87 & $-1.54^{\mathrm{d}}$ \\
\hline 5 & 0.08 & 0.00 & 0.00 & 0.04 & 0.00 & 0.00 & 0.00 & 0.00 & 0.87 & $0.01^{\mathrm{d}}$ \\
\hline S.E. & $0.008^{\mathrm{b}}$ & $0.004^{\mathrm{b}}$ & $0.005^{\mathrm{b}}$ & $0.013^{\mathrm{b}}$ & $0.001^{\mathrm{b}}$ & $0.027^{\mathrm{b}}$ & $0.026^{\mathrm{b}}$ & $0.008^{\mathrm{b}}$ & $0.005^{\mathrm{b}}$ & \\
\hline
\end{tabular}

${ }^{\text {a }}$ Proportional variance: $a^{2}$, direct genetic; $m^{2}$, maternal genetic; $p^{2}$, maternal permanent environmental; $c^{2}$, cytoplasmic line; $d y^{2}$, dam by year; $s d^{2}$, sire by dam; $s c^{2}$, sire by cytoplasmic line; $e^{2}$, temporary environmental; phenotypic variance: 0.3666 to 0.3668 .

${ }^{\mathrm{b}}$ Model not including genetic groups.

${ }^{\mathrm{c}}$ Difference in $2 \log$ likelihood from usual model $\left(1: a^{2}, m^{2}, p_{\mathrm{m}}^{2}, p_{\mathrm{a}}^{2}\right)$ with genetic groups in model.

${ }^{\mathrm{d}}$ Difference in $2 \log$ likelihood from usual model (3: $\left.a^{2}, m^{2}, p_{\mathrm{m}}^{2}, p_{\mathrm{a}}^{2}\right)$ with genetic groups not in model.

\subsection{Birth weight}

Estimates of direct and maternal heritability and the direct-maternal genetic correlation ( 0.25 to 0.27 , 0.19 to 0.20 and 0.02 to 0.05 , respectively) changed negligibly, if at all, when various factors were added to the usual model (Table 4). The estimate of variance due to maternal permanent environmental effects did change some depending on what other factors were in the model ( 0.07 with no other factors to 0.03 with all other factors in the model). Other factors added singly to the usual model accounted for as much as 0.11 (dam by year) and 0.10 (sire by dam) of the phenotypic variance. The obvious confounding among dam by year, dam by number born, and sire by dam interactions makes partitioning those variances difficult. Together the interactions with dams accounted for 0.13 to 0.14 of phenotypic variance. As with the previous studies, including dam by number born effects in the model added significantly to the likelihood even when dam by year effects were in the model. The variance component for dam by year is equivalent to the covariance of records within a dam by year group. The only way more than one lamb could be in the same dam by year subclass was when the ewe had more than one lamb in the litter. With all random factors in the model, the proportional estimate of variance due to sire by cytoplasmic line was zero, although the estimate was as large as 0.05 when added to the usual model. The model with sire by dam effects in addition to dam by year and dam by number born effects was not significant with the likelihood ratio test but did account for 0.03 of phenotypic variance with the full model. The total contribution of those three components of 0.13 to the phenotypic variance was similar but a little less than for the Columbia (0.16) and Targhee (0.15) analyses.

\subsection{Weaning weight}

Estimates of genetic parameters for 120-day weaning weight agreed with the pattern for the Columbia and Targhee analyses that the effects added to the usual direct-maternal effects model did not account for any of the phenotypic variance (Table 5). This result seems surprising for two reasons. Estimates for weaning weight might be expected to follow a pattern similar to that for birth weight. Secondly, for none of the other traits were estimates of the other components uniformly zero or exactly the same for the three breeds.

The estimate of the direct-maternal genetic correlation was larger $(0.30)$ than for the Columbia $(0.23)$ and Targhee $(-0.02)$ analyses. The other estimates of fractional variance were similar for the three breeds. Estimates of direct and maternal heritability were 0.18 and 0.10 and of fraction of variance due to maternal permanent environmental effects was 0.05 . 


\subsection{Fleece weight}

As with Columbia and Targhee analyses, direct heritability was large ( 0.55 vs. 0.53 and 0.57 for Columbia and Targhee, respectively). Although the relatively small maternal heritability ( 0.01 to 0.02$)$ led to the decision not to try to estimate the directmaternal genetic correlation, maternal genetic and permanent environmental effects contributed significantly to the phenotypic variance (Model 3 vs. Models 4 and 5). When included in the full model, variance due to dam by year, sire by dam and sire by cytoplasmic line interaction effects accounted for about 0.09 of phenotypic variance in agreement with 0.08 for Columbia and with 0.07 for Targhee. Most of that variance seems to have been partitioned from the animal permanent environmental variance (Model 10 vs. Model 3) as was also true for the Columbia and Targhee analyses. The estimate of fraction of variance due to sire by dam interaction $(0.05)$ was larger than for Columbia (0.02) and Targhee (0.00). The smaller estimates for Columbia and Targhee suggest that the sire by dam component for Rambouillet may be due to sampling variation for a relatively small parameter. The asymptotic standard error was about two-thirds $(0.033)$ the size of the estimate of 0.05 .

\subsection{Number born}

Estimates (Table 7) for the model with animal genetic and animal permanent environmental effects (fractional components of 0.08 and 0.04 ) agreed with estimates for Columbia (0.08 and 0.03$)$ and Targhee (0.10 and 0.04$)$. Estimates of no other components contributed to the phenotypic variance in contrast to the Columbia and Targhee analyses in which sire by cytoplasmic line variance $(0.01$ for Columbia and Targhee) and dam by year variance ( 0.02 for Targhee) were partitioned from the animal permanent environmental variance.

\section{Conclusion}

For Rambouillet sheep, cytoplasmic effects appear to be unimportant for birth, weaning, and fleece weights, and litter size born. Genetic evaluation models would not need to include cytoplasmic effects or sire by cytoplasmic effects. For weaning weight at 120 days, a model with direct and maternal genetic and maternal permanent environmental effects should be used for genetic evaluation. For fleece weight of ewes and litter size at birth as traits of the ewe, a sufficient model would include animal genetic and permanent environmental effects (repeatability model). For birth weight, a recommendation is more difficult. The model should include direct genetic and maternal genetic and maternal permanent environmental effects. Interactions of dam with year and with number born account for significant additional variation (about 0.10 of total variation) beyond that by the dam alone. Accounting for that variation may be of biological interest but may not be important for genetic evaluation.

\section{References}

Albuquerque, L.G., Keown, J.F., Van Vleck, L.D., 1998. Variances of direct genetic effects, maternal genetic effects, and cytoplasmic inheritance effects for milk yield, fat yield, and fat percentage. J. Dairy Sci. 81, 544-549.

Al-Shorepy, S.A., Notter, D.R., 1998. Genetic parameters for lamb birth weight in spring and autumn lambing. Anim. Sci. 67, 327-332.

Bell, B.R., McDaniel, B.T., Robison, O.W., 1985. Effects of cytoplasmic inheritance on production traits of dairy cattle. J. Dairy Sci. 68, 2038-2051.

Boettcher, P.J., Gibson, J.P., 1997. Estimation of variance of maternal lineage effects among Canadian Holsteins. J. Dairy Sci. $80,2167-2176$.

Boettcher, P.J., Freeman, A.E., Johnston, S.D., Smith, R.K., Beitz, D.C., McDaniel, B.T., 1996a. Relationship between polymorphism for mitochondrial deoxyribonucleic acid and yield traits of Holstein cows. J. Dairy Sci. 79, 647-654.

Boettcher, P.J., Kuhn, M.T., Freeman, A.E., 1996b. Impact of cytoplasmic inheritance on genetic evaluations. J. Dairy Sci. 79, $663-675$.

Boldman, K.G., Kriese, L.A., Van Vleck, L.D., Van Tassell, C.P., Kachman, S.D., 1995. A Manual for Use of MTDFREML. USDA-ARS, Clay Center, NE.

Dodenhoff, J., Van Vleck, L.D., Kachman, S.D., Koch, R.M., 1998. Parameter estimates for direct, maternal and grandmaternal genetic effects for birth weight and weaning weight in Hereford cattle. J. Anim. Sci. 76, 2521-2527.

Ercanbrack, S.K., Knight, A.D., 1991. Effects of inbreeding on reproduction and wool production of Rambouillet, Targhee, and Columbia ewes. J. Anim. Sci. 69, 4734-4744.

Gibson, J.P., Freeman, A.E., Boettcher, P.J., 1997. Cytoplasmic and mitochondrial inheritance of economical traits in cattle. Lives. Prod. Sci. 47, 115-124. 
Hanford, K.J., 2001. Estimates of genetic parameters and genetic change for prolificacy, weight, and wool characteristics of Columbia, Targhee and Polypay sheep. PhD Dissertation. University of Nebraska, Lincoln, 217 pp.

Hanford, K.J., Snowder, G.D., Van Vleck, L.D., 2003. Models with nuclear, cytoplasmic, and environmental effects for production traits of Columbia sheep. J. Anim. Sci. 81, 1926-1932.

Hiendleder, S., 1998. A low rate of replacement substitutions in two major Ovis aries mitochondrial genomes. Anim. Genet. 29 (2), $116-122$.

Johnson, D.L., Thompson, R., 1995. Restricted maximum likelihood estimation of variance components for univariate animal models using sparse matrix techniques and average information. J. Dairy Sci. 78, 449-456.

Kennedy, B.W., 1986. A further look at evidence for cytoplasmic inheritance of production traits in dairy cattle. J. Dairy Sci. 69, $3100-3105$.

Maniatis, N., Pollott, G.E., 2002. Nuclear, cytoplasmic, and environmental effects on growth, fat, and muscle traits in Suffolk lambs from a sire referencing scheme. J. Anim. Sci. 80, $57-67$.

Mannen, H., Kojima, T., Oyama, K., Mukai, F., Ishida, T., Tsuji, S., 1998. Effect of mitochondrial DNA variation on carcass traits of Japanese Black Cattle. J. Anim. Sci. 76, 36-41.

Pennisi, E., 2003. Gene counters struggle to get the right answer. Science 301, 1040-1041.

Roughsedge, T., Brotherstone, S., Visscher, P.M., 2001. Bias and power in the estimation of a maternal family variance compo- nent in the presence of incomplete and incorrect pedigree information. J. Dairy Sci. 84, 944-950.

Smith, S.P., Graser, H.-U., 1986. Estimating variance components in a class of mixed models by restricted maximum likelihood. J. Dairy Sci. 69, 1156-1165.

Sutovsky, P., Navara, C.S., Schatten, G., 1996. Fate of the sperm mitochondria, and the incorporation, conversion, and disassembly of the sperm tail structures during bovine fertilization. Biol. Reprod. 55, 1195-1205.

Terrill, C.E., 1947. Breed crosses used in the development of Targhee sheep. J. Anim. Sci. 6, 83-92.

Tess, M.W., Reodecha, C., Robison, O.W., 1987. Cytoplasmic genetic effects on preweaning growth and milk yield in Hereford cattle. J. Anim. Sci. 65, 675-684.

Tess, M.W., Robison, O.W., 1990. Evaluation of cytoplasmic genetic effects in beef cattle using an animal model. J. Anim. Sci. 68, 1899-1909.

Van Vleck, L.D., Snowder, G.D., Hanford, K.J., 2002. Models with cytoplasmic effects for birth, weaning and fleece weights, and litter size at birth for a population of Targhee sheep. J. Anim. Sci. 81, 61-67.

Westell, R.A., Quaas, R.L., Van Vleck, L.D., 1988. Genetic groups in an animal model. J. Dairy Sci. 71, 1310-1318.

Wolstenholme, D.R., 1992. Animal mitochondria-DNA: structure and evolution. Int. Rev. Cytol. 141, 173-216.

Wolz, W., Kress, W., Mueller, C.R., 1997. Genomic sequence and organization of the human gene for cytochrome $c$ oxidase subunit (COX7A1) VIIa-M. Genomics 45, 438-442. 